\title{
IDENTIFICATION PROCEDURES AND OPTIONS FOR REFORM
}

\author{
Yvette Tinsley*
}

This article was presented as a Victoria University of Wellington Centennial Lecture during Law Festival Week in 1999. The author notes that while the identification parade is officially the preferred method of identification in New Zealand, very few live parades are organised. Police officers prefer to use photographic identification, for which there is little procedural guidance or training resulting in an ad hoc development of police practice. It is argued in this article that regardless of the method used, a review of the supervision and training of police officers in the area of witness identification is urgently required.

This article incorporates qualitative research on identification procedures in New Zealand, funded by a Victoria University Internal Grant. More extensive research in the United Kingdom was completed for the author's doctoral thesis.

\section{INTRODUCTION}

In this paper, I want to give you an overview of how the conduct of identification procedures in New Zealand differs from recommended practice, and options for reform. In doing so, I will draw upon qualitative research I carried out in the four main centres of Dunedin, Christchurch, Wellington and Auckland.

The main methods of identification the police are allowed to use in New Zealand are:

- the identification parade;

- identification by photograph;

- informal identification.

* Lecturer, Faculty of Law, Victoria University of Wellington. 
Informal identification will be used where the suspect refuses to take part in an identification procedure, or where it is not possible to arrange a procedure.

There has recently been some movement towards the use of video identification, which may offer a viable alternative to the identification parade. However, the methods used for video identification need some careful review, a matter I will return to later in this paper.

Finally, dock identification is also used occasionally, and one of the police officers I spoke to preferred dock identification to any other method, despite evidence that it has little probative value. He preferred it because witnesses present as certain and emphatic, which is seen to be very persuasive for the jury.

In this paper, I want to explore why the identification parade, although recommended, is seldom used, and whether the alternatives used are resulting in satisfactory identification evidence. Where there is little official guidance, officers may fail to conduct identification procedures fairly, as shown by the much publicised case of $R v$ Walker, ${ }^{1}$ where video identification evidence was excluded. I do not have room in this short paper to explore what specific procedures would be most appropriate, but want to concentrate simply on the case for using consistent procedures, even where a formal identification parade has been refused or is impracticable. Recent events such as those in Walker highlight that the basics need to be addressed before we can get down to any detail.

\section{THE IDENTIFICATION PARADE}

The identification parade is officially the preferred method of identification. Examples illustrating this include:

- $\quad R v$ Hristov: 2 "It is standard practice police officers should follow".

- $\quad R v$ Tamihere: ${ }^{3}$ "The desirability of a properly conducted identification parade has been repeatedly stressed." Although the identification evidence was admitted in Tamihere, the Court was very critical of the methods used, and felt that a parade should have been held prior to publicity about Tamihere's identity.

$1 \quad R v$ Walker (8 May 1999) unreported, High Court, Auckland Registry, T98/1001.

2 Rv Hristov (1985) 8 CRNZ 158 (CA).

$3 \quad R v$ Tamihere [1991] 1 NZLR 195, 197 (CA). 
The Police Manual of Best Practice reflects the view that an identification parade should be considered before any other method, stating that: "formal identification parades are fair and carry more evidential weight than other methods", 4 and that informal identification and identification by photographs should be carried out only where a known suspect refuses or is unavailable for a parade.

This seems relatively clear and straightforward: in following the general line of the courts and their own 1997 guidelines, police officers should endeavour to use an identification parade before resorting to other methods. In fact, this does not happen in any police area in New Zealand. The identification parade is rarely considered, and would always be reserved for very serious cases. This was already the situation at the time the Manual was issued. The guidelines are out of touch with current practice, and the practice is certainly not coming into line with the guidelines. The current situation leaves a vacuum: the guidelines do not apply to most cases, but there is little guidance on performing a fair procedure by other methods. What results is an ad hoc and rather slapdash approach to identification evidence. One of the officers I interviewed extolled the virtues of having a national police service, yet in the realm of identification, there is a wide variance in practice up and down the country. That must be addressed.

However, there is no statutory requirement that an identification parade be held, and in line with current practice, some recent cases have led to a feeling of judicial support for the use of methods other than identification parades. For example, in $R v$ Harris, ${ }^{5}$ it was held that there was no general principle excluding identification evidence taken in circumstances other than an identification parade where one could have been held but was not. The Court acknowledged that parades had clear advantages over other methods, but that photographic evidence, for example, would still be admissible. The Court did not look for evidence of whether the parade does have viable alternatives, and did not consider what formal procedures we should insist the police follow.

The Court in $R v$ Porima and $W i^{6}$ re-iterated the sentiment in Harris that photographic evidence was admissible and relevant, and that there is no rule of law that photographic evidence should be excluded where an identification parade could have been held but was

4 Police Manual of Best Practice The Identification of Offenders (New Zealand Police, 1997) vol II, 314.

$5 \quad R v$ Harris (1991) 7 CRNZ 611 (CA).

$6 \quad$ R v Porima and Wi (1992) 9 CRNZ 368 (CA). 
not. ${ }^{7}$ However, the Court were also of the opinion that "at the evidential phase of the proceedings there is generally no need for the use of photographs so the prejudicial effect normally accompanying such use can be avoided". ${ }^{8}$ This is certainly not my understanding of police procedures regarding identification evidence, where the use of photographs is far more common than the parade.

Some police officers I spoke to felt that comments such as the one in Harris meant that the parade was no longer the officially preferred method. This is patently not the approach of the judiciary, yet most officers proceed as though it is. The Court in $R v$ Dixon $^{9}$ as recently as 1997, stated that the parade was seen to be the preferred method, and that although it may be that the police have changed their practice, the courts would need evidence about the procedures followed, as well as evidence of their experience with formal identification parades, before any review of the appropriateness of the use of photographs can be undertaken. ${ }^{10}$ Officers continue to go ahead without offering that evidence and without any internal review of procedures. It is not the ideal way to move forward with new methods, and creates a rather uncertain environment for police and defendants alike.

The police officers I spoke to in the four main centres could count on one hand the number of identification parades conducted in their area in the last five years. Some comments made include:

-I conducted one in 1995, but it would be 15 years since the last one was carried out in this station.

- No one can recall an ID parade being carried out in this station.

-I've spent 11 years in CIB, and can recall only two parades.

-I know of only one in the last year.

-In the three or four years I've been [at this station], I have never been involved in a formal ID parade.

7 In $R v$ Porima and $W i$, a parade was not practicable due to the distinctive appearance of the suspects.

$8 \quad R v$ Porima and Wi above $\mathrm{n}$ 6, 371 per Eichelbaum CJ.

$9 \quad R v$ Dixon (25 June 1997) unreported, Court of Appeal, CA 77/97.

$10 R v$ Dixon above $\mathrm{n}$ 9, 5 per Gault J, referring to $R v$ Porima and $W i$ above $\mathrm{n}$ 6, 367. 
-I would usually expect to know if there is one out of [this station], and I've been doing this for three years and I cannot recall one in that time. Not one.

-I spoke to a prosecutor yesterday who has been prosecuting here for seven years, he has never had a file where an identification parade has been used.

It is sensible to ask here whether the small number of identification procedures conducted can be attributed to a general decline in the use of eyewitness identification evidence. As the officers I spoke to were clear that eyewitness evidence was an issue in a high proportion of the cases they dealt with, the notion that there is little need to gather the evidence can be discounted. A review of high profile cases reveals that they continue to involve an element of eyewitness evidence: see for example Tamihere, $R v$ Dougherty, ${ }^{11}$ Walker, and the recent trial of Scott Watson. The healthy use of identification by photographs throughout New Zealand suggests that, rather than a decline in the frequency and importance of eyewitness identification evidence in criminal cases, there has been a shift in the methods used to gather such evidence.

\section{A Why No Parades?}

It is clear that eyewitness identification evidence is still used in many cases, but that identification parades have fallen into disuse. I was told by one officer that sometimes the police may consider an identification parade, but that the idea is "discounted almost immediately". I asked the officers I spoke to why that was, and they cited the following reasons for conducting so few identification parades:

- Finding suitable volunteers;

- The strain on police resources;

- Lack of victim willingness;

- $\quad$ Lack of suspect willingness (and solicitor approval).

Finding suitable volunteers can be a genuine problem, especially as some towns are sparsely populated. Officers also spoke about the change in attitudes of both employers and the population at large: employers are less likely to allow their employees to take an afternoon helping the police, and people would be reluctant to give up part of their day for little reward other than knowing they had done their "civic duty". In England and Wales, the purpose-built

11 Rv Dougherty (1996) 14 CRNZ 145 (CA). 
Identification Suites popping up in every city have employed various strategies to find volunteers, including using employment agencies. Volunteers are paid between seven and 15 pounds for each parade. Some unemployed young men supplement their government benefit very well by appearing as a volunteer on five or six identification parades a week. However, the cost of identification procedures in both police time and money has risen to a ridiculous extent in England and Wales, as a parade must be held wherever eyewitness identification is an issue in the case. England and New Zealand are at opposite extremes. What is needed is a happy medium.

Victim and non-victim willingness is also a genuine problem in a country where there are only two police stations equipped with a one-way screen. Officers spoke of feelings of intimidation experienced by witnesses who had to confront a violent offender face to face, especially in gang-related cases. For all witnesses, the horror of re-living the offence was felt to increase where the identification procedure took the form of a live parade. Officers were all of the opinion that photographs shielded witnesses somewhat.

It is unlikely that suspects will agree to participate in an identification procedure of any kind, not just the parade, and this gives officers little option but to carry out an informal procedure of one form or another. Legal representatives often advise their clients to refuse to participate, even though they are aware that some form of informal identification will probably take place anyway. However, this does not prevent officers using procedures which are as close as possible to those used in a formal, consensual identification parade, group or video.

\section{IDENTIFICATION BY PHOTOGRAPHS}

Traditionally, identification by photographs in New Zealand was viewed in a similar way to its use in England and Wales: it should be used only for investigative purposes when the suspect is not known; or in exceptional circumstances for evidential purposes where the suspect is known.

Photographic identification is the preferred method of identification amongst New Zealand police today, with officers citing some positive advantages:

- Photo montages, where a number of photographs are placed on a board, are quick and easy to arrange. Fewer staff are involved, fewer resources and much less "hassle" than when a parade has to be organised: "photographs are the easiest, the quickest because you are not having to arrange for people to attend at a certain time and at a certain place"; 
- Witnesses prefer to look at photographs rather than having to go through the harrowing experience of confronting the offender. Photographs can be shown in the comfort of the witness' own home;

- The suspect is not directly involved.

The increase in acceptance of photographic identification evidence is despite well documented problems. However, these difficulties are not insurmountable:

- The photograph cannot represent the suspect in a real and natural setting, it is a two dimensional representation. One of the heralded advantages of a live procedure is that it offers a quality of representation unmatched by any other form of identification. This was certainly true until very recently, but with the advance of photographic and video quality, it is almost certain that the gap between live and photographic representation has diminished greatly;

- Where there is a later identification parade, there can be a prejudicial effect because the witness' original memory may be replaced by the one in the photograph. This is a very rare problem in an environment where parades are seldom used at all;

- Evidence of identification from photographs may also be prejudicial in that it may suggest to the witness or the jury that the suspect has a police record;

- Unlike the showing of the photograph of a live parade to the jury, photo-montages would usually be considered prejudicial if they consisted of a series of "mug-shots". Therefore, the jury cannot judge the fairness of the montage for themselves. If the defence do want to challenge the fairness of the evidence, they have to pay by risking that the jury will be further prejudiced by seeing the photographs and assuming that the defendant has a criminal record. One Wellington barrister said to me that:

It's very difficult to cross-examine because you're running a two-edged sword with your cross-examination, because you don't want to put the picture in the mind of the jury that this guy has a photograph of some sort in a mug book.

Using photographs which are not mug shots obviously alleviates the latter two difficulties.

In observing the cases coming to court and in speaking to police officers, the only sensible conclusion to reach is that photographs have replaced parades as the accepted method of identification in New Zealand. As one Wellington barrister stated:

If there is an identification to be done, the photographs are the first thing that is considered. 
I would say invariably the police would be showing photographs...That's normal practice I think.

Although the most popular method of identification, there is little uniformity of procedural approach in the showing of photographs. Police officers spoken to in my recent study gave little or no consensus on such issues as: what instructions to give to witnesses, how many photographs to show, and whether the investigating officer should be the one to show the photographs.

\section{VIDEO IDENTIFICATION}

With video identification, some of the advantages of identification parades, such as the suspect being seen in a real setting, could be added to the advantages of photographs in that it would be quicker and less stressful for witnesses. Some of the disadvantages of photographs could be overcome: for example there would be no suggestion that the accused had a criminal record because there would not be "mug shots". The success of the idea largely depends on the way it is run:

- Using footage of civilian volunteers for the library would be preferable to the use of other suspects. A national video library could be formed, and footage could be used again and again. However, people are likely to be even more reluctant to appear on a film retained by the police than in a one off parade in the police station. Payment and the use of people from employment agencies could work;

- The reluctance of legal representatives to advise their clients to take part in formal identification procedures could cause difficulties. If suspects are filmed covertly it will become difficult to film them performing the same act, with the same background and lighting, as the volunteers contained in the video libraries. This could result in unfairness, as the suspect would stand out from other members of the parade;

- Running sequential, rather than simultaneous, video parades will be preferable. ${ }^{12}$ This will allow for libraries to be kept rather than a new parade having to be formed each time. It is also likely to make for better evidence as psychological research shows that sequential viewing results in fewer false identifications. ${ }^{13}$

12 In a sequential parade, members are shown to the witness one at a time, rather than all at once.

13 False identifications may be reduced because the scope for simple comparison is reduced. The phenomenon is termed the "relative judgment process". See R C L Lindsay, J A Lea, and J A Fulford "Sequential Lineup Presentation: Technique Matters" (1991) 76 Journal of Applied Psychology 741. 
In Walker, the prejudicial nature of mug shots was multiplied by representation in video of the suspect and others being interviewed by police officers. What was supposed to be an advance on photographic identification could actually be said to be a step backwards. Further, the other members of the video parade were of greatly varied skin tone, and many had facial hair or long hair, as opposed to the suspect who was clean shaven with cropped hair. The Court was not against video identification as such, but rightly viewed the process as unfair. Lockhart J stated that: ${ }^{14}$

Of the 10 individuals being interviewed only three (including the Respondent) were clean shaven...All other seven shown being interviewed had facial hair in the form of beards, or moustaches or long hair or dreadlocks in contrast to the Respondent who had short cropped hair. The two individuals who were clean shaven (apart from the Respondent) had rather different distinctive features from the Respondent in that [one]...had almost negroid features and was very dark-skinned while [the other]...had a distinctive shaven bald head. Mrs Smith...acknowledged that it was easy for her to exclude from the individuals she saw on the composite video tape those who had long hair, facial hair. And those who appeared extremely bulky.

Even if we are generous and say the victim chose from three videos, this falls well short of the six parade members recommended by psychologists. ${ }^{15}$ These differences in appearance were major, and any supervision or training of the officer involved should have prevented such a biased parade. Walker highlights the need for a uniform procedure, and adequate supervision regarding the composition of parades, be they live, photographic or video.

Procedural rules are inadequate without supervision and training in how to apply those rules. An example of this can be found in England and Wales, where the Code of Practice is detailed and stringent, but where South Yorkshire police managed to stage an identification parade which was so unfair that Astill J described it as a "farce". ${ }^{16}$ In the knowledge that an identification parade was the preferred procedure, officers had attempted to arrange one even

$14 R v$ Walker above $\mathrm{n} 1,10$ per Lockhart $\mathrm{J}$.

15 Five volunteers, or "distractors", for each suspect. See G L Wells, E P Seelau, S M Rydell, and C A Luus "Recommendations for Properly Conducted Lineup Identification Tasks" in D F Ross, J D Read and M P Toglia (eds) Adult Eyewitness Testimony: Current Trends and Developments (Cambridge University Press, New York, 1994) 223, 229.

16 See "Star of the Black and White Identity Parade" The Times, London, England, 25 July 1997, Home News section; "Suspect Freed after Black and White Lineup" The Daily Telegraph, London, England, 25 July 1997, 3 . 
where suitable volunteers could not be found. The suspect was six foot three inches tall, weighed 16 stone, was black and bald. Officers found white volunteers who, apart from the colour of their skin, fitted the description of the suspect, and "blacked" their faces with makeup. The Code of Practice makes provision for situations where volunteers cannot be found by allowing a group identification, video identification or confrontation, ${ }^{17}$ but it was a lack of supervision and training which led to officers rejecting those alternatives in favour of the "completely ludicrous procedure" 18 of blacking the faces of white men. ${ }^{19}$ The suspect was very generous under the circumstances, stating that "the police were racist in an ignorant sort of way, not a bigoted sort of way". ${ }^{20}$ His case highlights that rules alone cannot ensure fair and consistent procedures. Supervision by senior officers and ongoing training are also needed. In New Zealand we have the unhappy situation of inadequate procedural guidelines, poor supervision, and rudimentary training. Small wonder unfair procedures take place.

\section{$V$ OPTIONS FOR REFORM AND CONCLUSION}

The problem lies not in the mode of identification used, but in the lack of routine, formal procedures for the police to follow. New Zealand has moved to the use of photographic identification without thinking about changes in procedure and re-visiting the training of staff. The move away from parades is based in large part on legitimate concerns, but it happened on an ad hoc, unofficial basis, and there does not appear to have been an official "catching up" with what is happening on the ground. There should be some process undertaken to review whether the change in approach is the right way to move, what changes in procedure and training are required, and what the legal implications of any changes would be. Officers should not be given free rein to carry out new procedures at will. If they continue to do so, more cases like Walker will result.

A lack of certainty will almost certainly result in more dispute and a greater amount of case law questioning the fairness of police practice. It also makes the job of the judiciary more

17 A confrontation is where the witness is shown the suspect on his or her own. It is sometimes called a "show-up".

18 Rosie Winterton, Labour MP for Doncaster Central.

19 Other examples of inappropriately constructed identification parades include volunteers being given wigs and makeup because the suspect was Rastafarian; and white volunteers being requested to impersonate a suspect from Pakistan: see "We Name the Innocent Men" The Evening Standard, London, England, 9 October 1997, 23.

20 Quoted in The Independent London, England, 26 July 1997, 6. 
difficult when deciding whether or not to exclude potentially unfairly obtained evidence. Where there is no formal procedure, it is difficult to make decisions based on the need to maintain effective control of that procedure. Issues of fairness become more malleable. And, as stated by Cooke P in Tamihere, "irregular identification techniques by the police can jeopardise the course of justice". 21

There is confusion and lack of structure to the law on identification in New Zealand. I have not had time to explore what specific procedures would be most appropriate, but hope that I have started a process of moving back to a nationally applied approach for a national police service.

$21 R v$ Tamihere above $\mathrm{n}$ 3, 203 per Cooke $\mathrm{P}$. 
(2000) 31 VUWLR 
